in vivo $35: 1345-1354(2021)$

doi:10.21873/invivo.12387

Review

\title{
Newly-identified Pathways Relating Vitamin D to Carcinogenesis: A Review
}

\author{
NADEEM BILANI ${ }^{1}$, LEAH ELSON ${ }^{1}$, CHARLES SZUCHAN $^{1}$, \\ ELIZABETH ELIMIMIAN ${ }^{1}$, MUSTAFA SALEH $^{2}$ and ZEINA NAHLEH ${ }^{1}$ \\ ${ }^{1}$ Department of Hematology-Oncology, Cleveland Clinic Florida, Weston, FL, U.S.A.; \\ ${ }^{2}$ Lebanese University, Fanar, Lebanon
}

\begin{abstract}
Background: The epidemiological relationship between vitamin D levels and cancer has been thoroughly investigated. Published data from large studies appear to corroborate a significant relationship between higher serum vitamin D concentrations and improved survival. Mechanistic reviews on commonly-studied cancers - including breast cancer, colon cancer and melanoma - focus predominantly on data from older studies. In outlining avenues for future research, we believe there is utility in summarizing novel findings introduced to the literature. Materials and Methods: In this narrative review, we used MEDLINE, PUBMED and Cochrane databases to identify mechanistic studies published from January 1, 2015 onwards exploring this topic. Results: Twenty-five mechanistic studies were included in this review. It was found that vitamin D plays a critical role in both direct (i.e. tumor gene expression, proliferation, invasiveness, sensitivity to chemotherapy etc.) and indirect (i.e. effects on the tumor microenvironment and immunomodulation) tumor suppression mechanisms. Conclusion: These newly-identified pathways warrant further research, with the hopes that we may understand how and when vitamin D supplementation can be integrated into precision medicine therapeutics for cancers of the breast, colon and skin. Cancer care providers should consider recommendations to screen for vitamin $D$ deficiency in this population.
\end{abstract}

This article is freely accessible online.

Correspondence to: Nadeem Bilani, Department of HematologyOncology, Cleveland Clinic Florida, 2950 Cleveland Clinic Blvd., Weston, FL 33331. U.S.A. Tel: +1 9544872264, email: bilanin@ccf.org

Key Words: Vitamin D, cholecalciferol, ergocalciferol, calcitriol, cancer risk, survival, breast cancer, colorectal cancer; skin cancer, review.
Vitamin D is a fat-soluble vitamin that exists in two forms: vitamin D2 (ergocalciferol) and vitamin D3 (cholecalciferol) $(1,2)$. Dietary consumption of UVB-exposed plants and fungi is the primary source of vitamin D2 in humans $(3,4)$. Vitamin D3 can also be obtained through diet, mostly from oily fish. However, over $90 \%$ of the body's daily vitamin D requirements are produced in the skin upon exposure to sunlight (5).

After consumption or synthesis of vitamin D, both forms must be hydroxylated to become biologically active. The first hydroxylation occurs in the liver to create the compound 25-hydroxyvitamin D. This molecule is the major circulating form of vitamin D in the human body, and therefore is used as a diagnostic marker of deficiency (2). Subsequently, it is hydroxylated again in the kidney to form 1,25dihydroxyvitamin $\mathrm{D}$, the metabolically-active form of vitamin D. 1,25-dihydroxyvitamin D plays a crucial role in a number of processes, most notably calcium and phosphorus homeostasis (2).

The US Preventive Services Task Force (USPSTF) has not made specific recommendations with regards to screening for vitamin D deficiency in asymptomatic patients (6), yet literature has demonstrated that there are wide disparities in average serum vitamin D levels in different populations across the world - with individuals from Africa and the Middle East being of particular risk for deficiency (7).

The association between vitamin D deficiency and carcinogenesis has been studied thoroughly over the last two decades (5), but the potential role of vitamin D supplementation in cancer care is not yet clear. The vitamin D receptor (VDR) is a member of the steroid nuclear receptor family. Its activation results in receptor dimerization and downstream recruitment of vitamin D response elements (VDREs) that form a regulatory complex modulating gene expression (8). Cancer cell lines expressing VDR exhibit inhibited cellular proliferation when exposed to 1,25dihydroxyvitamin D in cultures of prostate, colon, breast, lung, and skin (5). Recent reviews summarizing the mechanistic 


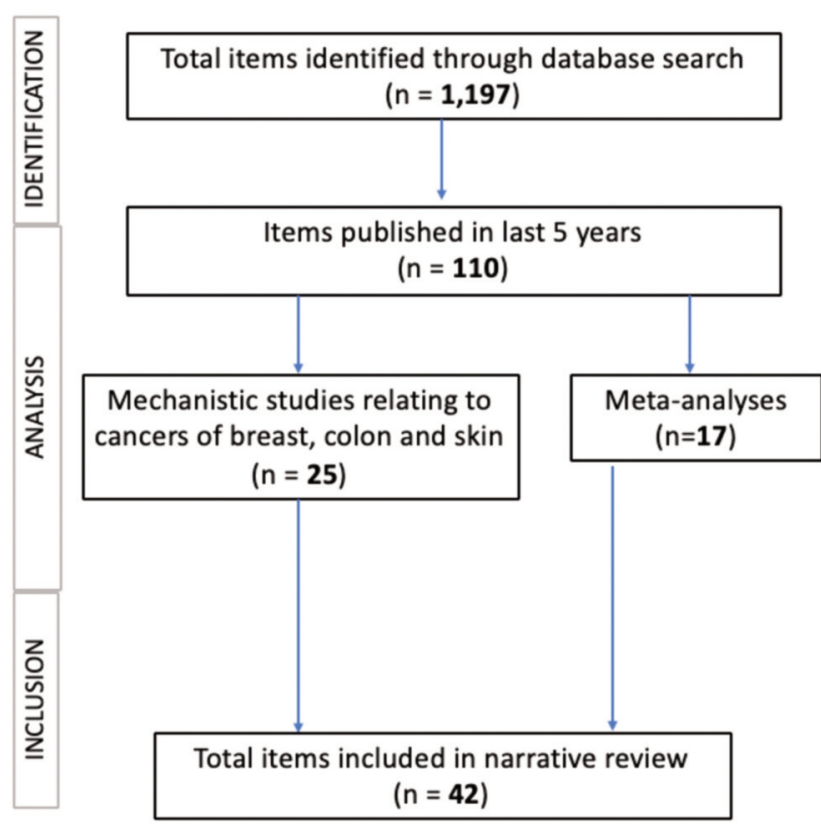

Figure 1. Flow chart outlining algorithm of article inclusion.

relationship between vitamin $\mathrm{D}$ and cancer have focused heavily on older studies (9-13). In outlining new areas for future research, we believe there is utility in summarizing these novel molecular mechanisms and assessing how they fit into the context of existing models relating vitamin $\mathrm{D}$ to cancer.

Thus, in this review, we evaluate literature published over the last five years to explore the underlying molecular biology linking vitamin $\mathrm{D}$ to carcinogenesis, focusing on the most commonly reported cancer subtypes: breast cancer, colon cancer, and melanoma.

\section{Materials and Methods}

A literature search was conducted using PUBMED, MEDLINE and Cochrane databases to capture peer-reviewed research articles (including reviews and meta-analyses), published between January 1, 2015 and August 20, 2020. Articles in any language were included if an English translation existed.

The initial step of the search strategy involved combining the following MeSH terms with the boolean operator OR: "Vitamin D", "Ergocalciferol", "Cholecalciferol", "Calcitriol", "Calcifediol", "Vitamin D Deficiency" as well as the keyword "hydroxyvitamin D". This created the first search string. The MeSH term "Neoplasms" was then combined with the keyword "cancer" using the OR Boolean operator to create the second search string. Consequently, both search strings were combined. All collected abstracts were surveyed by two, independent researcher associates in order to confirm article relevancy to the proposed study topics. Data extraction was performed on the included articles that met our review objectives.

\section{Results}

A total of 1,197 articles were produced by the aforementioned search strategy. This was parsed down to 1,383 after selecting for articles that focused on breast cancer (BC), colorectal cancer (CRC) or melanoma (the three, most commonly reported malignancies). The authors chose to review mechanistic studies published in the last 5 years in order to harvest data that best represents contemporary knowledge. As a result, 25 were then eligible after excluding duplicated studies or lack of relatedness based on abstract summaries. Additionally, to show the breadth of epidemiological data published on this topic, we presented all 17 meta-analyses captured by our search in one summary table. The flow chart in Figure 1 presents the full inclusion schema of articles analyzed for this review.

A significant portion of the literature explored the mechanisms governing the association between vitamin $\mathrm{D}$ and tumorigenesis. These mechanisms can be broadly categorized into two main groups: those pertaining to a direct effect on cancer cells (e.g. tumor gene expression, proliferation, invasiveness, sensitivity to chemotherapy etc.) and those associated with indirect effects (e.g. effects on the tumor microenvironment and immunomodulation), as outlined in Figure 2.

Vitamin $D$ as a modulator of tumor aggressiveness. We identified 11 major mechanisms describing the direct effects of vitamin D on tumor aggressiveness. These mechanisms are corroborated by clinical data revealing an association between reduced vitamin $\mathrm{D}$ levels and markers of poor prognosis, including: regional lymph node positivity, resistance to chemotherapy, and metastasis (14).

Vitamin D modulates a number of multifunctional transcriptional complexes. i) Mouse models with VDR gene knockouts exhibit increased expression of a helix-loop-helix transcription factor known as the "inhibitor of differentiation" (Id1) (8). This is associated with higher rates of BC tumor growth and metastasis. Id1 is also implicated in epithelial-tomesenchymal transitioning (EMT), angiogenesis and tumor invasiveness (15). ii) In the MCF-7 BC cell line, calcitriol and its analog tacalcitol, also decrease the expression of MiR$125 \mathrm{~b}$ (16); a member of a class of microRNAs that regulates post-transcriptional gene expression and is known to promote BC cell migration, invasiveness and chemosensitivity (16). iii) Vitamin D acts antagonistically toward retinoid-related orphan receptor (ROR) alpha and gamma; transcription factors expressed in all major skin populations that may be intimately involved in melanoma tumorigenesis (17). iv) Finally, vitamin D binds the beta-catenin transcriptional complex, reducing nuclear B-catenin content and upregulating Wnt inhibitor molecules (e.g. ROCK, p38 MAPK, and MSK1 kinases) (13). $\beta$-catenin signaling is 


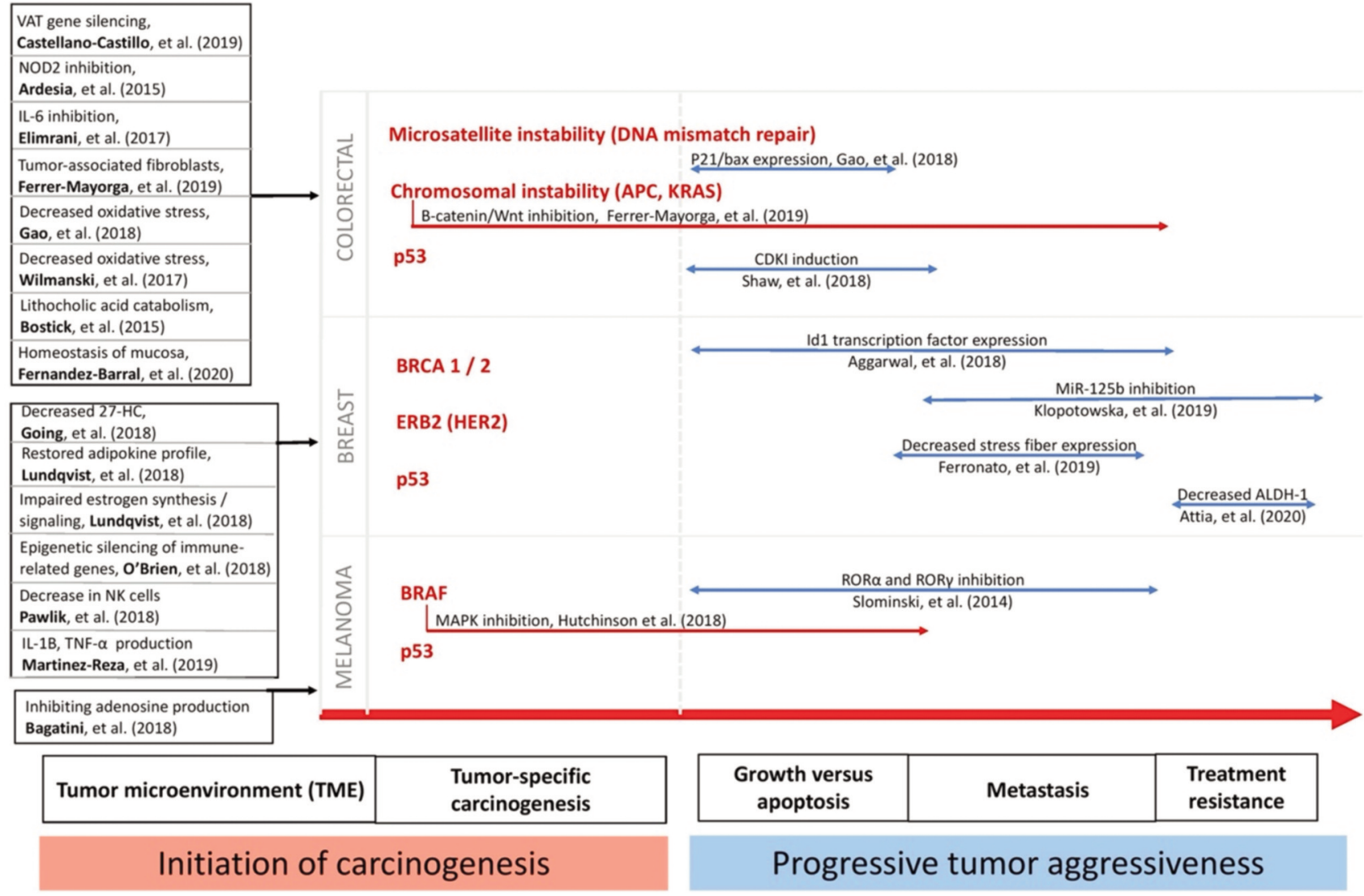

Figure 2. Overview of newly-identified mechanisms relating vitamin D to carcinogenesis or disease progression.

involved in malignant transformation, increased proliferation and migration of colorectal cells (13). Important to note is the potential distinction recently made between colitis-associated colon cancer and other sporadic or inherited colon cancers. Meeker et al. (2020) reported decreased colon tumor incidence and severity of colonic dysplasia in mouse models for colitis-associated colon cancer (CAC) fed with vitamin Dnull diets, likely due to higher epithelial cell proliferation associated with vitamin D deficiency that is more optimal for healthy homeostasis of inflamed mucosa. v) In malignant melanoma, vitamin D has also been related to mitogenactivated protein kinase (MAPK) signaling, which is known to affect phosphorylation and regulation of transcription factors, co-regulatory proteins and chromatin proteins (18).

Vitamin D modulates cellular proliferation through checkpoint regulators. vi) Vitamin D may cause cell-cycle arrest in G1 via decreased expression of the cyclin D1 (19). This mechanism initiates apoptosis when cancer cells detach from the extracellular matrix (ECM), thereby limiting the metastatic potential of malignant cells. vii) Vitamin D can also influence checkpoint regulation through induction of cyclin- dependent kinase inhibitors (CDKIs), specifically p21 and $\mathrm{p} 27^{\mathrm{KIP} 1}(13,19)$. This finding is corroborated by an RCT investigating calcium and vitamin $\mathrm{D}$ supplementation over a 6-month period in patients with sporadic colorectal adenomas. Increased expression of p21 (a marker of differentiation) and bax (a marker of apoptosis) was noted (20).

Vitamin D also modulates cellular migration. viii) Calcitrioltreated BC cells demonstrate decreased expression of stress fibers (cytoskeletal structures composed of actin), impairing cellular migration and invasiveness (21). ix) Calcitriol has also been shown to positively regulate the expression of adhesion molecules (e.g. E-cadherin, occludin, claudin, plectin, and filamin A), which contributes to an increased stability of epithelial barriers and cell-to-cell adhesion (13). This may be mediated through vitamin D-related inhibition of Sprouty-2, a protein which deregulates E-cadherin. One surprising pathway was identified by Anisiewicz et al. (2018), showing a x) net pro-metastatic effect of vitamin D on mouse models for basallike breast cancer tumor expression of osteopontin (OPN) (22). No other studies identified such an unfavorable impact on metastatic capacity. 
Finally, vitamin D may also modulate responsiveness of cancer cells to therapy. xi) Vitamin D3 has been shown to enhance breast cancer stem cell responsiveness to conventional chemotherapeutic agents through downregulating expression of the enzyme aldehyde dehydrogenase-1 (ALDH1) (23). This has been described more thoroughly in Section 3.3: Vitamin D and Clinical Practice.

Vitamin $D$ and the tumor microenvironment. A cancerous mass consists of not only malignant cells but also adjacent resident or infiltrating host cells, secreted factors and the surrounding ECM. This is known as the tumor microenvironment. With the advent of immunotherapy and other forms of precision medicine, cancer research has expanded its focus to include analysis of the tumor microenvironment. We identified 14 major mechanisms related to the indirect effects of vitamin D on tumorigenesis.

Vitamin D signaling modulates numerous immune mediators. i) Vitamin D concentrations are significantly associated with DNA methylation (a form of epigenetic modulation) of $\mathrm{CpG}$ regions of immune function-related genes in BC patients, effectively silencing their expression (24). Pawlik et al. (2018) noted that calcitriol and its analogs contribute to tumor-conducive changes in tumor-bearing mice (25). Specifically, she noted a ii) decrease in NK CD335+ cells in model spleen and lymph nodes after supplementation with vitamin D. iii) In triple negative breast cancer (TNBC) cell lines, calcitriol exerts an antiproliferative effect through the production of cytokines IL$1 \mathrm{~B}$ and TNF- $\alpha$ (26). This is in contrast to the two prior studies that highlighted potential immune suppression.

Vitamin D also modulates hormonal or metabolic cascades implicated in cancer. Estrogen is a known driving force behind BC growth, particularly in postmenopausal or obese women (8). iv) Vitamin D blocks estrogenic signaling at multiple steps: it inhibits estrogen synthesis (through downregulation of CYP19A1, which encodes for the aromatase, among other mechanisms) and also downregulates estrogen receptor signaling (27). v) Vitamin $\mathrm{D}$ also restores the adipokine profile (decreased leptin signaling and increased adiponectin signaling) dysregulated by obesity. In a trial of 29 BC patients, Going et al. (2018) noted that vi) high-dose (10,000 IU/day) supplementation of vitamin D decreased circulating 27-hydroxycholesterol (27HC) levels compared to supplementation of low-dose vitamin D (400 IU/day) (28). This is associated with inhibition of CYP27A1, the enzyme that normally synthesizes $27 \mathrm{HC}$. The $27 \mathrm{HC}$ protein is an endogenous selective estrogen receptor modulator (SERM) which accelerates the growth of ER receptor positive BC.

Adipose tissue is also implicated in CRC tumorigenesis. vii) Vitamin D might play a role in epigenetic modification of visceral adipose tissue (VAT) genes through DNA- methyltransferase. Adipose tissue DNMT3A mRNA is both negatively associated with serum vitamin D levels and positively associated with adipose tissue VDR and $\mathrm{NfkB} 1$ methylation (29). This VAT microenvironment is associated with chronic, obesity-associated low-grade inflammation, insulin resistance and angiogenesis (29). viii) Moreover, with respect to inflammation, vitamin $\mathrm{D}$ has been shown to block nucleotide-binding oligomerization domain-containing protein 2 (NOD2), which is implicated in inflammatory bowel disease (30), and to decrease expression of the inflammatory cytokine interleukin-6 (IL-6), independent of NOD2 (31).

Finally, vitamin D modulates homeostatic processes of surrounding tissue. Tumor-associated fibroblasts alter the extracellular matrix and facilitate the migration of carcinoma cells (13). ix) VDR is found on these fibroblasts and elevated VDR in these cells is associated with longer overall survival in CRC (32). x) Vitamin D facilitates calcium and phosphate absorption in the gut. Higher serum calcium levels can bind bile acids and fatty acids, thereby reducing oxidative DNA damage (20) that may indirectly contribute to tumorigenesis. In breast cell lines, oxidative stress is prevented via transcriptional downregulation of pyruvate carboxylase upon treatment with vitamin D (33). xi) VDR activation also up-regulates CYP3A4, and this was shown to favor an anti-tumorigenic microenvironment by catabolism of toxic lithocholic acid (34). xii) In melanoma, the active form of vitamin D reduces AMP hydrolysis and adenosine production, likely through ecto-5'nucleotidase/CD73 activity (35). Adenosine is one of the primary immunosuppressive metabolites in the tumor microenvironment (36), possibly contributing to increased tumor cell viability. Resident gut microbiota has also been implicated in the carcinogenesis of CRC (37). xiii) Calcitriol supplementation to CYP27B1 knockout mice may modulate this through reduced Helicobacter titers and severity of inflammation in colitis. xiv) Fernandez-Barral reported vitamin D-related expression of stemness-related genes, which is hypothesized to contribute to the homeostasis of healthy colonic mucosa in regeneration upon injury (38).

Vitamin D and clinical practice. At the time of this review, the National Cancer Institute reported the inclusion of cholecalciferol in 8 clinical trials. This includes a randomized phase IIb trial, examining the preventative effects of vitamin D supplementation, for lung cancer, in chronic obstructive pulmonary disease patients (COPD), as well as a partially randomized early phase I trial examining vitamin D in colon cancer patients with liver metastasis. Furthermore, many investigators have identified avenues for future consideration of vitamin D supplementation in the clinical setting.

Hypercalcemia is a toxic effect of vitamin D supplementation that limits the extent of its applicability in the clinical setting. Multiple studies have investigated means to avoid this. Ferronato et al. (2019) proposes the use of 
calcitriol analogs, such as ML-344 (which has an amide and carboxyl group in its side chain) that display anti-tumor, but not hypercalcemic, effects (21). Wang et al. also notes that vitamin D signaling mediated by specific cytochrome $\mathrm{P} 450$ enzymes (CYP11A1 and CYP3A4) is noncalcemic and antiproliferative, identifying potential new targets for therapy (39). Finally, Nicolas et al. (2018) explores new mechanisms of delivery, such as polymeric nanocapsules as drug carriers for calcitriol, that are efficacious but nontoxic (40).

A number of preclinical studies have investigated the potential utility of vitamin $\mathrm{D}$, combined with traditional chemotherapy regimens, in order to enhance the antitumorigenic effects of these treatments while minimizing side effects. Lim et al. (2018) reported synergism between ruxolitinib and calcitriol in the treatment of an estrogen receptor-positive, human epidermal growth factor receptor 2positive BC cell line (41). Pre-treatment with vitamin D analogues potentiates TNF- $\alpha$ cytotoxic effects through impaired cell viability as well as DNA fragmentation (26). Synergism has also been reported between vitamin D and tamoxifen (42), histone deacetylase inhibitors (43), paclitaxel (44), dacarbazine and cisplatin (45), 5-fluorouracil (5-FU) (46), bevacizumab (47), immune checkpoint inhibitors (48), and the nutraceutical S-adenosylmethionine (SAM).

Vitamin D may have utility in improving quality of life overall in cancer patients. Recent literature has described the relationship between vitamin $\mathrm{D}$ deficiency and immunosuppression, particularly as it relates to safety for patients with cancer during the COVID-19 pandemic (49). However, randomized controlled trials investigating the use of vitamin D for patients with COVID-19 pneumonia showed it was not significantly associated with changes in duration of hospital stay, rate of ICU admission or mechanical ventilation requirement (50). Vitamin D is also commonly prescribed, along with other pharmaceuticals, to prevent or minimize iatrogenic osteoporosis in patients receiving estrogen-depleting therapy for breast cancer (51). Deficiency may be related to medication-related osteonecrosis of the jaw, a rare complication of bisphosphonates that are often incorporated into care for these patients (52). Additionally, in a recent clinical trial, Keshavarzi et al. (2019) showed that vitamin D vaginal suppositories also improve vaginal atrophy in women with BC on tamoxifen (53).

Epidemiological studies. Large-scale epidemiological studies, evaluating the association between vitamin D and cancer incidence (54-61) or mortality (7, 62-70), have provided consistent results. Table I outlines a summary of the meta-analyses published over the last five years on this topic. The relationship between higher serum vitamin D levels and favorable outcomes in patients who already have cancer is more consistently corroborated than the hypothesis that deficiency may increase the risk of developing cancer.

\section{Discussion}

This review indicates that while there is strong evidence to show vitamin D levels may be related to morbidity and mortality outcomes in patients with cancer, our understanding of the molecular interplay between vitamin D and different neoplasms is still evolving.

Large epidemiological studies displayed consistency in these findings that serum vitamin $\mathrm{D}$ is not likely related to the risk of developing cancer, but is likely significantly related to cancer mortality, as outlined in Table I. Gaulao et al. (which did not yield a significant combined effect of vitamin D on mortality) included trials with short periods of follow-up (the longest trial exhibited a median follow-up of 6.2 years). These shorter follow-up intervals may not be of adequate length to capture relevant information in the context of BC survival (54). Meta-regressions in the study by Zhang et al. revealed that all-cause mortality was indeed significantly decreased in studies with longer follow-up periods (62), re-iterating the limited scope of the Gaulao et al. review, and its inconclusive results. The review by Keum et al. is limited in the diversity of included study populations, which were composed predominantly of white patients (63). This is a noteworthy limitation considering non-white individuals, particularly those of African and Middle Eastern descent, are more likely to suffer from vitamin D deficiency. Additionally, studies exploring the vitamin $\mathrm{D}$ effect in skin cancer also offered mixed results regarding whether vitamin $\mathrm{D}$ is protective or potentially deleterious (71). More work is thus needed to verify that the significant protective relationship is consistent across a diverse group of patients.

Interestingly, these significant results of preclinical studies, over the last five years, seem to corroborate the findings of meta-analyses suggesting that functional vitamin D pathways may play a role in improving cancer outcomes but not necessarily attenuating cancer risk. Studies investigating for an association between VDR and previously-established initiating pathways of malignancy did not yield significant results. Irving et al. (2018) showed no relationship between vitamin D and adenomatous polyposis coli (APC) gene functioning, one of the first tumor suppressors defective in the adenoma-carcinoma sequence, implicated in both sporadic and familial forms of colorectal cancer (72). Similarly, Kwan et al. (2019) failed to show a significant effect between vitamin D supplementation and colorectal mucosa expression of MSH2, known to be involved in the DNA mismatch repair mechanisms that are defective in Lynch syndrome (73). Figure 2 presents significant molecular findings relating vitamin D and tumorigenesis, published over the last five years, in a timeline. It shows that vitamin $\mathrm{D}$ deficiency may favor a microenvironment conducive to tumor growth and is also directly implicated in more aggressive, chemo-resistant disease. However, a paucity of 
in vivo $35: 1345-1354(2021)$

Table I. Overview of meta-analyses published over the last 5 years exploring the relationship between vitamin D and cancer risk/prognosis.

\begin{tabular}{|c|c|c|c|c|c|c|}
\hline & Source & Outcome(s) & Exposure & $\begin{array}{l}\text { \# Included studies } \\
\text { (Sample size) }\end{array}$ & Effect & $p$-Value \\
\hline \multirow[t]{15}{*}{ Nonspecific } & \multirow{2}{*}{$\begin{array}{l}\text { Keum et al. } \\
\text { (2019) (63) }\end{array}$} & Incidence & \multirow[t]{2}{*}{ Supplementation } & 10 RCTs $(83,353)$ & $\mathrm{RR}=0.98(95 \% \mathrm{CI}=0.83-1.09)$ & 0.42 \\
\hline & & $\begin{array}{l}\text { All-cause } \\
\text { mortality }\end{array}$ & & 5 RCTs $(75,239)$ & $\mathrm{RR}=0.87(95 \% \mathrm{CI}=0.79-0.96)$ & 0.005 \\
\hline & \multirow[t]{5}{*}{$\begin{array}{l}\text { Zhang et al. } \\
\text { (2019) (62) }\end{array}$} & $\begin{array}{l}\text { All-cause } \\
\text { mortality }\end{array}$ & \multirow[t]{5}{*}{ Supplementation } & $\begin{array}{l}42 \text { RCTs using vitamin D3 } \\
(57,910)\end{array}$ & $\mathrm{RR}=0.95(95 \% \mathrm{CI}=0.90-1.00)$ & 0.06 \\
\hline & & & & $\begin{array}{c}10 \text { RCTs using vitamin D2 } \\
(17,554)\end{array}$ & $\mathrm{RR}=0.98(95 \% \mathrm{CI}=0.95-1.02)$ & 0.3 \\
\hline & & $\begin{array}{l}\text { Cancer-related } \\
\text { mortality }\end{array}$ & & 12 RCTs $(45,578)$ & $\mathrm{RR}=0.84(95 \% \mathrm{CI}=0.74-0.95)$ & 0.006 \\
\hline & & $\begin{array}{l}\text { Cardiovascular } \\
\text { mortality }\end{array}$ & & 12 RCTs $(43,306)$ & $\mathrm{RR}=0.98(95 \% \mathrm{CI}=0.88-1.08)$ & 0.64 \\
\hline & & $\begin{array}{c}\text { Non-cancer, } \\
\text { non-cardiovascular } \\
\text { mortality }\end{array}$ & & 4 RCTs (36174) & $\mathrm{RR}=1.05(95 \% \mathrm{CI}=0.93-1.18)$ & 0.44 \\
\hline & \multirow{2}{*}{$\begin{array}{l}\text { Goulão et al. } \\
(2018)(54)\end{array}$} & Incidence & \multirow[t]{2}{*}{ Supplementation } & 24 RCTs $(18,440)$ & $\mathrm{RR}=1.03(95 \% \mathrm{CI}=0.91-1.15)$ & 0.911 \\
\hline & & $\begin{array}{l}\text { Cancer-related } \\
\text { mortality }\end{array}$ & & 17 RCTs $(15,893)$ & $\mathrm{RR}=0.85(95 \% \mathrm{CI}=0.70-1.04)$ & 0.679 \\
\hline & \multirow[t]{3}{*}{$\begin{array}{l}\text { Gaksch et al. } \\
\text { (2017) (64) }\end{array}$} & \multirow[t]{3}{*}{$\begin{array}{l}\text { All-cause } \\
\text { mortality }\end{array}$} & $\begin{array}{l}\text { Serum vitamin D } \\
\text { concentration of } \\
40-49.99 \mathrm{nmol} / 1 \\
\text { vs. } 75-99.99 \mathrm{nmol} / 1\end{array}$ & 8 cohort studies $(26,916)$ & $\mathrm{HR}=1.15(95 \% \mathrm{CI}=1-1.29)$ & $>0.05$ \\
\hline & & & $\begin{array}{l}\text { Serum vitamin D } \\
\text { concentration of } \\
30-39.99 \mathrm{nmol} / 1 \\
\text { vs. } 75-99.99 \mathrm{nmol} / 1\end{array}$ & & $\mathrm{HR}=1.33(95 \% \mathrm{CI}=1.16-1.51)$ & $<0.05$ \\
\hline & & & $\begin{array}{l}\text { Serum vitamin D } \\
\text { concentration of } \\
<30 \mathrm{nmol} / 1 \mathrm{vs} \text {. } \\
75-99.99 \mathrm{nmol} / 1\end{array}$ & & $\mathrm{HR}=1.67(95 \% \mathrm{CI}=1.44-1.89)$ & $<0.05$ \\
\hline & \multirow{2}{*}{$\begin{array}{l}\text { Vaughan-Shaw } \\
\text { et al. } \\
(2017)(65)\end{array}$} & $\begin{array}{l}\text { Overall } \\
\text { survival }\end{array}$ & \multirow{2}{*}{$\begin{array}{l}\text { Highest } v s . \text { lowest } \\
\text { quartile serum } \\
\text { vitamin D } \\
\text { concentration }\end{array}$} & $\begin{array}{c}38 \text { studies - mixed design } \\
(24,013)\end{array}$ & $\mathrm{HR}=0.74(95 \% \mathrm{CI}=0.66-0.82)$ & $<0.05$ \\
\hline & & $\begin{array}{l}\text { Progression- } \\
\text { free survival }\end{array}$ & & $\begin{array}{c}23 \text { studies - mixed design } \\
(14,307)\end{array}$ & $\mathrm{HR}=0.84(95 \% \mathrm{CI}=0.77-0.91)$ & $<0.05$ \\
\hline & $\begin{array}{l}\text { Bjelakovic et al. } \\
\text { (2014) (66) }\end{array}$ & $\begin{array}{l}\text { All-cause } \\
\text { mortality }\end{array}$ & Supplementation & 4 RCTs $(44,492)$ & $\mathrm{RR}=0.88(95 \% \mathrm{CI}=0.78-0.98)$ & 0.02 \\
\hline \multirow[t]{9}{*}{$\begin{array}{l}\text { Breast } \\
\text { cancer }\end{array}$} & \multirow[t]{3}{*}{$\begin{array}{l}\text { Estébanez et al. } \\
\text { (2018) (56) }\end{array}$} & \multirow[t]{3}{*}{ Risk } & $\begin{array}{l}\text { Serum vitamin D } \\
\text { concentration }\end{array}$ & 3 case-control studies (1958) & $\mathrm{OR}=0.61(95 \% \mathrm{CI}=0.33-1.16)$ & $>0.05$ \\
\hline & & & Supplementation 5 & 5 case-control studies $(15,758)$ & $\mathrm{OR}=0.78(95 \% \mathrm{CI}=0.63-0.98)$ & $<0.05$ \\
\hline & & & & 2 cohort studies $(62,412)$ & $\mathrm{RR}=1.06(95 \% \mathrm{CI}=0.90-1.25)$ & $>0.05$ \\
\hline & \multirow[t]{2}{*}{$\begin{array}{l}\text { Hossain et al. } \\
(2018)(57)\end{array}$} & \multirow[t]{2}{*}{ Risk } & $\begin{array}{l}\text { Serum vitamin D } \\
\text { concentration }\end{array}$ & $\begin{array}{c}14 \text { case-control studies } \\
(123,044)\end{array}$ & $\mathrm{RR}=0.99(95 \% \mathrm{CI}=0.98-1.00)$ & 0.17 \\
\hline & & & $\begin{array}{l}\text { Serum vitamin } D \\
\text { deficiency }\end{array}$ & 5 case-control studies (2796) & $\mathrm{RR}=1.91(95 \% \mathrm{CI}=1.51-2.41)$ & $<0.001$ \\
\hline & $\begin{array}{l}\text { Hu et al. } \\
(2018) \text { (7) }\end{array}$ & $\begin{array}{l}\text { Overall } \\
\text { survival }\end{array}$ & $\begin{array}{c}\text { Serum vitamin D } \\
\text { concentration (highest } \\
\text { versus lowest category) }\end{array}$ & $\begin{array}{l}6 \text { cohort studies (5984) } \\
\text { t }\end{array}$ & $\mathrm{HR}=0.67(95 \% \mathrm{CI}=0.56-0.79)$ & $<0.001$ \\
\hline & \multirow[t]{3}{*}{$\begin{array}{l}\text { Kim et al. } \\
(2014)(58)\end{array}$} & Risk & $\begin{array}{c}\text { Serum vitamin D } \\
\text { concentration (highest }\end{array}$ & $\begin{array}{c}24 \text { case-control or } \\
\text { cohort studies }(31,867)\end{array}$ & $\mathrm{RR}=0.92(95 \% \mathrm{CI}=0.83-1.02)$ & $>0.05$ \\
\hline & & $\begin{array}{l}\text { All-cause } \\
\text { mortality }\end{array}$ & versus lowest category) & $\begin{array}{l}6 \text { case-control or } \\
\text { cohort studies (6092) }\end{array}$ & $\mathrm{RR}=0.61(95 \% \mathrm{CI}=0.48-0.79)$ & $<0.05$ \\
\hline & & $\begin{array}{l}\text { Cancer-related } \\
\text { mortality }\end{array}$ & & $\begin{array}{l}6 \text { case-control or } \\
\text { cohort studies (4556) }\end{array}$ & $\mathrm{RR}=0.58(95 \% \mathrm{CI}=0.40-0.85)$ & $<0.05$ \\
\hline \multirow[t]{2}{*}{$\begin{array}{l}\text { Colorectal } \\
\text { cancer }\end{array}$} & \multirow[t]{2}{*}{$\begin{array}{l}\text { Maalmi et al. } \\
(2018)(67)\end{array}$} & $\begin{array}{l}\text { Overall } \\
\text { survival }\end{array}$ & $\begin{array}{l}\text { Serum vitamin D } \\
\text { (highest versus }\end{array}$ & 11 cohort studies (7718) & $\mathrm{HR}=0.68(95 \% \mathrm{CI}=0.55-0.85)$ & $<0.05$ \\
\hline & & $\begin{array}{l}\text { CRC-specific } \\
\text { survival }\end{array}$ & lowest category) & 8 cohort studies $(6756)$ & $\mathrm{HR}=0.67(95 \% \mathrm{CI}=0.57-0.78)$ & $<0.05$ \\
\hline
\end{tabular}


Table I. Continued

\begin{tabular}{|c|c|c|c|c|c|c|}
\hline & Source & Outcome(s) & Exposure & $\begin{array}{l}\text { \# Included Studies } \\
\text { (Sample Size) }\end{array}$ & Effect & $p$-Value \\
\hline & \multirow[t]{3}{*}{$\begin{array}{l}\text { Xu et al. } \\
(2018)(68)\end{array}$} & $\begin{array}{l}\text { Overall } \\
\text { survival }\end{array}$ & $\begin{array}{l}\text { Serum vitamin D } \\
\text { (highest versus }\end{array}$ & 11 cohort studies (7367) & $\mathrm{HR}=0.67(95 \% \mathrm{CI}=0.55-0.80)$ & $<0.00001$ \\
\hline & & $\begin{array}{l}\text { Progression- } \\
\text { free survival }\end{array}$ & \multirow[t]{2}{*}{ lowest category) } & 2 cohort studies (599) & $\mathrm{HR}=0.74(95 \% \mathrm{CI}=0.61-0.90)$ & 0.003 \\
\hline & & $\begin{array}{c}\text { CRC-specific } \\
\text { survival }\end{array}$ & & 5 cohort studies (4126) & $\mathrm{HR}=0.74(95 \% \mathrm{CI}=0.61-0.90)$ & 0.03 \\
\hline & $\begin{array}{l}\text { Ekmekcioglu } \\
\text { et al. } \\
(2017)(59)\end{array}$ & Risk & $\begin{array}{l}\text { Serum vitamin D } \\
\text { (highest versus } \\
\text { lowest category) }\end{array}$ & $\begin{array}{l}26 \text { case-control or } \\
\text { cohort studies }(42,258)\end{array}$ & $\mathrm{RR}=0.83(95 \% \mathrm{CI}=0.76-0.90)$ & $<0.05$ \\
\hline & $\begin{array}{l}\text { Garland et al. } \\
(2017)(60)\end{array}$ & Risk & $\begin{array}{l}\text { Serum vitamin D } \\
\text { (highest versus } \\
\text { lowest category) }\end{array}$ & $\begin{array}{c}15 \text { case-control studies } \\
(175,127)\end{array}$ & $\mathrm{OR}=0.67(95 \% \mathrm{CI}=0.59-0.76)$ & $<0.05$ \\
\hline & $\begin{array}{l}\text { Choi et al. } \\
(2015)(61)\end{array}$ & Risk & $\begin{array}{l}\text { Serum vitamin D } \\
\text { (highest versus } \\
\text { lowest category) }\end{array}$ & $\begin{array}{l}15 \text { studies - mixed design } \\
(12,110)\end{array}$ & $\mathrm{OR}=0.68(95 \% \mathrm{CI}=0.54-0.82)$ & $<0.05$ \\
\hline & $\begin{array}{l}\text { Ou et al. } \\
(2015)(69)\end{array}$ & $\begin{array}{c}\text { All-cause mortality } \\
\text { Cancer-related mortality }\end{array}$ & $\begin{array}{l}\text { Serum vitamin D } \\
\text { y (highest versus } \\
\text { lowest category) }\end{array}$ & 5 cohort studies $(3761)$ & $\begin{array}{l}\mathrm{OR}=0.80(95 \% \mathrm{CI}=0.67-0.95) \\
\mathrm{OR}=0.72(95 \% \mathrm{CI}=0.57-0.92)\end{array}$ & $\begin{array}{l}<0.05 \\
<0.05\end{array}$ \\
\hline Melanoma & $\begin{array}{l}\text { Mahamat-Saleh } \\
\text { et al. } \\
(2020)(74)\end{array}$ & Risk & $\begin{array}{l}\text { Serum vitamin D } \\
\text { (highest versus } \\
\text { lowest category) }\end{array}$ & $\begin{array}{c}6 \text { cohort studies } \\
(241,893)\end{array}$ & $\mathrm{RR}=1.42(95 \% \mathrm{CI}=1.17-1.72)$ & $<0.05$ \\
\hline
\end{tabular}

studies have reported a relationship to the function of tumor suppressor genes (such as BRCA, APC, TP53) or oncogenes (such as HER2 and BRAF) known to be primary genetic defects in many malignancies (74).

\section{Conclusion}

This review sought to evaluate the most recently-identified molecular mechanisms governing the relationship between vitamin D and carcinogenesis, as well as the clinical impact of vitamin $\mathrm{D}$ deficiencies on cancer risk and prognosis. It was found that vitamin D plays a critical role in both direct and indirect tumor suppression mechanisms. Supporting the wealth of studies highlighting relevant biological pathways are also a number of meta-analyses identifying a significant association between normalized vitamin D levels and improved survival. However, the impact on cancer risk was not found to be significant. More work is needed to understand if the observed protective effects persist across the different analogs of vitamin $\mathrm{D}$, different races, and different disease processes. While the USPSTF does not make recommendations to screen for vitamin $\mathrm{D}$ deficiency in asymptomatic individuals, it can be diagnosed through a simple blood test and is commonly performed in a wide variety of clinical contexts. Noting that this information may be readily available to their patients, cancer care providers should consider supplementation in cases of deficiency as a significant component of holistic care.

\section{Conflicts of Interest}

The Authors declare no conflicts of interest.

\section{Authors' Contributions}

Conceptualization, N.B., L.E. and Z.N.; methodology, N.B., C.S and L.E.; writing-original draft preparation, N.B., C.S., L.E. and Z.N.; writing-review and editing, N.B., C.S., L.E., E.E., M.S., and Z.N.; supervision, Z.N.

\section{References}

1 Holick MF: Sunlight and vitamin D for bone health and prevention of autoimmune diseases, cancers, and cardiovascular disease. Am J Clin Nutr 80(6 Suppl): 1678S-1688S, 2004. PMID: 15585788. DOI: 10.1093/ajcn/80.6.1678S

2 Chen TC and Holick MF: Vitamin D and prostate cancer prevention and treatment. Trends Endocrinol Metab 14(9): 423430, 2003. PMID: 14580762. DOI: 10.1016/j.tem.2003.09.004

3 Jäpelt RB and Jakobsen J: Vitamin D in plants: a review of occurrence, analysis, and biosynthesis. Front Plant Sci 4: 136, 2013. PMID: 23717318. DOI: 10.3389/fpls.2013.00136

4 Lips P: Vitamin D physiology. Prog Biophys Mol Biol 92(1): 4-8, 2006. PMID: 16563471. DOI: 10.1016/j.pbiomolbio.2006.02.016

5 Holick MF: Vitamin D: its role in cancer prevention and treatment. Prog Biophys Mol Biol 92(1): 49-59, 2006. PMID: 16566961. DOI: 10.1016/j.pbiomolbio.2006.02.014

6 LeFevre ML: Screening for vitamin D deficiency in adults: US Preventive Services Task Force recommendation statement. Ann 
Intern Med 162(2): 133-140, 2015. PMID: 25419853. DOI 10.7326/M14-2450

$7 \mathrm{Hu} \mathrm{K}$, Callen DF, Li J and Zheng H: Circulating vitamin D and overall survival in breast cancer patients: A dose-response metaanalysis of cohort studies. Integr Cancer Ther 17(2): 217-225, 2018. PMID: 28589744. DOI: 10.1177/1534735417712007

8 Aggarwal A, Feldman D and Feldman BJ: Identification of tumor-autonomous and indirect effects of vitamin $\mathrm{D}$ action that inhibit breast cancer growth and tumor progression. J Steroid Biochem Mol Biol 177: 155-158, 2018. PMID: 28710021. DOI: 10.1016/j.jsbmb.2017.07.003

9 Fleet JC, DeSmet M, Johnson R and Li Y: Vitamin D and cancer: a review of molecular mechanisms. Biochem J 441(1): 61-76, 2012. PMID: 22168439. DOI: 10.1042/BJ20110744

10 Skrajnowska D and Bobrowska-Korczak B: Potential molecular mechanisms of the anti-cancer activity of vitamin D. Anticancer Res 39(7): 3353-3363, 2019. PMID: 31262856. DOI: 10.21873/ anticanres. 13478

11 Carlberg C and Muñoz A: An update on vitamin D signaling and cancer. Semin Cancer Biol: S1044-579X(20)30114-0, 2020. PMID: 32485310. DOI: 10.1016/j.semcancer.2020.05.018

12 Blasiak J, Pawlowska E, Chojnacki J, Szczepanska J, Fila M and Chojnacki C: Vitamin D in triple-negative and BRCA1-deficient breast cancer-implications for pathogenesis and therapy. Int J Mol Sci 21(10), 2020. PMID: 32456160. DOI: 10.3390/ijms21103670

13 Ferrer-Mayorga G, Larriba MJ, Crespo P and Muñoz A: Mechanisms of action of vitamin D in colon cancer. J Steroid Biochem Mol Biol 185: 1-6, 2019. PMID: 29981368. DOI: 10.1016/j.jsbmb.2018.07.002

14 Micheletti PL, de Borba Cecílio da Silva AP, Rech D, Victorino VJ, do Amaral Herrera ACDS, Kern R, Pires BR, Simão ANC, Bortoloti DS, Panis C and Dichi I: Low Plasmatic 25hydroxyvitamin D at Diagnosis is Associated with Axillary Invasion, Chemoresistance and Metastasis in Women with Breast Cancer. Arch Med Res 51(6): 542-547, 2020. PMID: 32507367. DOI: $10.1016 /$ j.arcmed.2020.05.014

15 Roschger $\mathrm{C}$ and Cabrele $\mathrm{C}$ : The Id-protein family in developmental and cancer-associated pathways. Cell Commun Signal 15(1): 7, 2017. PMID: 28122577. DOI: 10.1186/s12964016-0161-y

16 Klopotowska D, Matuszyk J and Wietrzyk J: Steroid hormone calcitriol and its analog tacalcitol inhibit miR-125b expression in a human breast cancer MCF-7 cell line. Steroids 141: 70-75, 2019. PMID: 30503385. DOI: 10.1016/j.steroids.2018.11.014

17 Slominski AT, Kim TK, Takeda Y, Janjetovic Z, Brozyna AA, Skobowiat C, Wang J, Postlethwaite A, Li W, Tuckey RC and Jetten AM: ROR $\alpha$ and ROR $\gamma$ are expressed in human skin and serve as receptors for endogenously produced noncalcemic 20hydroxy- and 20,23-dihydroxyvitamin D. FASEB J 28(7): 27752789, 2014. PMID: 24668754. DOI: 10.1096/fj.13-242040

18 Hutchinson PE, Halsall JA, Popovici S, Papadogeorgakis E, Osborne JE, Powley IR, Dasari D, Saldanha G and Pringle JH: Compromised vitamin $\mathrm{D}$ receptor signalling in malignant melanoma is associated with tumour progression and mitogenactivated protein kinase activity. Melanoma Res 28(5): 410-422, 2018. PMID: 30004989. DOI: 10.1097/CMR.0000000000000475

19 Shaw E, Massaro N and Brockton NT: The role of vitamin D in hepatic metastases from colorectal cancer. Clin Transl Oncol 20(3): 259-273, 2018. PMID: 28801869. DOI: 10.1007/s12094$017-1735-x$
20 Gao Y, Um CY, Fedirko V, Rutherford RE, Seabrook ME, Barry EL, Baron JA and Bostick RM: Effects of supplemental vitamin $\mathrm{D}$ and calcium on markers of proliferation, differentiation, and apoptosis in the normal colorectal mucosa of colorectal adenoma patients. PLoS One 13(12): e0208762, 2018. PMID: 30557404. DOI: 10.1371 /journal.pone.0208762

21 Ferronato MJ, Obiol DJ, Alonso EN, Guevara JA, Grioli SM, Mascaró M, Rivadulla ML, Martínez A, Gómez G, Fall Y, Quevedo MA, Curino AC and Facchinetti MM: Synthesis of a novel analog of calcitriol and its biological evaluation as antitumor agent. J Steroid Biochem Mol Biol 185: 118-136, 2019. PMID: 30125657. DOI: 10.1016/j.jsbmb.2018.08.006

22 Wei R, Wong JPC and Kwok HF: Osteopontin - a promising biomarker for cancer therapy. J Cancer 8(12): 2173-2183, 2017. PMID: 28819419. DOI: 10.7150/jca.20480

23 Attia YM, Hammam OA, Ammar RA, Mansour MT and Elmazar MM: Crosstalk between aldehyde dehydrogenase- 1 and chemoresistance in breast cancer: Insights into the role of vitamin D3. Life Sci 253: 117733, 2020. PMID: 32360127. DOI: 10.1016/j.lfs.2020.117733

24 O'Brien KM, Sandler DP, Xu Z, Kinyamu HK, Taylor JA and Weinberg CR: Vitamin D, DNA methylation, and breast cancer. Breast Cancer Res 20(1): 70, 2018. PMID: 29996894. DOI: 10.1186/s13058-018-0994-y

25 Pawlik A, Anisiewicz A, Filip-Psurska B, Nowak M, Turlej E, Trynda J, Banach J, Gretkierewicz P and Wietrzyk J: Calcitriol and its analogs establish the immunosuppressive microenvironment that drives metastasis in 4T1 mouse mammary gland cancer. Int J Mol Sci 19(7): 2116, 2018. PMID: 30037009. DOI: 10.3390/ijms 19072116

26 Martínez-Reza I, Díaz L, Barrera D, Segovia-Mendoza M, Pedraza-Sánchez S, Soca-Chafre G, Larrea F and García-Becerra $\mathrm{R}$ : Calcitriol inhibits the proliferation of triple-negative breast cancer cells through a mechanism involving the proinflammatory cytokines IL-1 $\beta$ and TNF- $\alpha$. J Immunol Res 2019: 6384278, 2019. PMID: 31093512 . DOI: $10.1155 / 2019 / 6384278$

27 Lundqvist J, Kirkegaard T, Laenkholm AV, Duun-Henriksen AK, Bak M, Feldman D and Lykkesfeldt AE: Williams syndrome transcription factor (WSTF) acts as an activator of estrogen receptor signaling in breast cancer cells and the effect can be abrogated by $1 \alpha, 25$-dihydroxyvitamin $\mathrm{D}_{3}$. J Steroid Biochem Mol Biol 177: 171-178, 2018. PMID: 28610873. DOI: 10.1016/ j.jsbmb.2017.06.003

28 Going CC, Alexandrova L, Lau K, Yeh CY, Feldman D and Pitteri SJ: Vitamin D supplementation decreases serum 27hydroxycholesterol in a pilot breast cancer trial. Breast Cancer Res Treat 167(3): 797-802, 2018. PMID: 29116467. DOI: 10.1007/s10549-017-4562-4

29 Castellano-Castillo D, Morcillo S, Crujeiras AB, SánchezAlcoholado L, Clemente-Postigo M, Torres E, Tinahones FJ and Macias-Gonzalez M: Association between serum 25hydroxyvitamin D and global DNA methylation in visceral adipose tissue from colorectal cancer patients. BMC Cancer 19(1): 93, 2019. PMID: 30665376. DOI: 10.1186/s12885-018-5226-4

30 Ardesia M, Ferlazzo $G$ and Fries W: Vitamin D and inflammatory bowel disease. Biomed Res Int 2015: 470805, 2015. PMID: 26000293. DOI: $10.1155 / 2015 / 470805$

31 Elimrani I, Koenekoop J, Dionne S, Marcil V, Delvin E, Levy E and Seidman EG: Vitamin D Reduces Colitis- and InflammationAssociated Colorectal Cancer in Mice Independent of NOD2. 
Nutr Cancer 69(2): 276-288, 2017. PMID: 28045548. DOI: 10.1080/01635581.2017.1263346

32 Ferrer-Mayorga G, Gómez-López G, Barbáchano A, FernándezBarral A, Peña C, Pisano DG, Cantero R, Rojo F, Muñoz A and Larriba MJ: Vitamin D receptor expression and associated gene signature in tumour stromal fibroblasts predict clinical outcome in colorectal cancer. Gut 66(8): 1449-1462, 2017. PMID: 27053631. DOI: $10.1136 /$ gutjnl-2015-310977

33 Wilmanski T, Zhou X, Zheng W, Shinde A, Donkin SS, Wendt M, Burgess JR and Teegarden D: Inhibition of pyruvate carboxylase by $1 \alpha, 25$-dihydroxyvitamin $\mathrm{D}$ promotes oxidative stress in early breast cancer progression. Cancer Lett 411: 171181, 2017. PMID: 29024812. DOI: 10.1016/j.canlet.2017.09.045

34 Bostick RM: Effects of supplemental vitamin D and calcium on normal colon tissue and circulating biomarkers of risk for colorectal neoplasms. J Steroid Biochem Mol Biol 148: 86-95, 2015. PMID: 25597952. DOI: 10.1016/j.jsbmb.2015.01.010

35 Bagatini MD, Bertolin K, Bridi A, Pelinson LP, da Silva Rosa Bonadiman B, Pillat MM, Gonçalves PBD, Ulrich H, Schetinger MRC and Morsch VM: 1 $\alpha, 25$-Dihydroxyvitamin D3 alters ectonucleotidase expression and activity in human cutaneous melanoma cells. J Cell Biochem 120(6): 9992-10000, 2019. PMID: 30548323 . DOI: $10.1002 /$ jcb.28281

36 Umansky V, Shevchenko I, Bazhin AV and Utikal J: Extracellular adenosine metabolism in immune cells in melanoma. Cancer Immunol Immunother 63(10): 1073-1080, 2014. PMID: 24756420. DOI: 10.1007/s00262-014-1553-8

37 Johnson CH, Dejea CM, Edler D, Hoang LT, Santidrian AF, Felding BH, Ivanisevic J, Cho K, Wick EC, Hechenbleikner EM, Uritboonthai W, Goetz L, Casero RA Jr, Pardoll DM, White JR, Patti GJ, Sears CL and Siuzdak G: Metabolism links bacterial biofilms and colon carcinogenesis. Cell Metab 21(6): 891-897, 2015. PMID: 25959674. DOI: 10.1016/j.cmet.2015.04.011

38 Fernández-Barral A, Costales-Carrera A, Buira SP, Jung P, Ferrer-Mayorga G, Larriba MJ, Bustamante-Madrid P, Domínguez O, Real FX, Guerra-Pastrián L, Lafarga M, GarcíaOlmo D, Cantero R, Del Peso L, Batlle E, Rojo F, Muñoz A and Barbáchano A: Vitamin D differentially regulates colon stem cells in patient-derived normal and tumor organoids. FEBS J 287(1): 53-72, 2020. PMID: 31306552. DOI: 10.1111/febs. 14998

39 Wang P, Qin X, Liu M and Wang X: The burgeoning role of cytochrome $\mathrm{P} 450$-mediated vitamin $\mathrm{D}$ metabolites against colorectal cancer. Pharmacol Res 133: 9-20, 2018. PMID: 29719203. DOI: $10.1016 /$ j.phrs.2018.04.022

40 Nicolas S, Bolzinger MA, Jordheim LP, Chevalier Y, Fessi H and Almouazen E: Polymeric nanocapsules as drug carriers for sustained anticancer activity of calcitriol in breast cancer cells. Int J Pharm 550(1-2): 170-179, 2018. PMID: 30118832. DOI: 10.1016/j.ijpharm.2018.08.022

41 Lim ST, Jeon YW, Gwak H, Kim SY and Suh YJ: Synergistic anticancer effects of ruxolitinib and calcitriol in estrogen receptor-positive, human epidermal growth factor receptor 2-positive breast cancer cells. Mol Med Rep 17(4): 5581-5588, 2018. PMID: 29436642. DOI: 10.3892/mmr.2018.8580

42 Zheng W, Duan B, Zhang Q, Ouyang L, Peng W, Qian F, Wang $\mathrm{Y}$ and Huang S: Vitamin D-induced vitamin D receptor expression induces tamoxifen sensitivity in MCF-7 stem cells via suppression of Wnt/ $\beta$-catenin signaling. Biosci Rep 38(6): BSR20180595, 2018. PMID: 30314996. DOI: 10.1042/BSR20180595
43 Bijian K, Kaldre D, Wang TT, Su J, Bouttier M, Boucher A, Alaoui-Jamali M, White JH and Gleason JL: Efficacy of hybrid vitamin $\mathrm{D}$ receptor agonist/histone deacetylase inhibitors in vitamin D-resistant triple-negative 4T1 breast cancer. J Steroid Biochem Mol Biol 177: 135-139, 2018. PMID: 28847749. DOI: 10.1016/j.jsbmb.2017.08.010

44 Wilhelm CA, Clor ZJ and Kelts JL: Effect of vitamin D on paclitaxel efficacy in triple-negative breast cancer cell lines. Anticancer Res 38(9): 5043-5048, 2018. PMID: 30194148. DOI: 10.21873/anticanres. 12823

45 Piotrowska A, Wierzbicka J, Rybarczyk A, Tuckey RC, Slominski AT and Żmijewski MA: Vitamin D and its low calcemic analogs modulate the anticancer properties of cisplatin and dacarbazine in the human melanoma A375 cell line. Int J Oncol 54(4): 1481-1495, 2019. PMID: 30968156. DOI: 10.3892/ ijo. 2019.4725

46 Klopotowska D and Matuszyk J: VDR agonists increase sensitivity of mcf-7 and bt- 474 breast cancer cells to $5 \mathrm{fu}$. Anticancer Res 40(2): 837-840, 2020. PMID: 32014926. DOI: 10.21873/anticanres.14015

47 Lipplaa A, Fernandes R, Marshall A, Lorigan P, Dunn J, Myers KA, Barker E, Newton-Bishop J, Middleton MR and Corrie PG: 25-hydroxyvitamin $\mathrm{D}$ serum levels in patients with high risk resected melanoma treated in an adjuvant bevacizumab trial. $\mathrm{Br}$ J Cancer 119(7): 793-800, 2018. PMID: 30033445. DOI: 10.1038/s41416-018-0179-6

48 Stucci LS, D’Oronzo S, Tucci M, Macerollo A, Ribero S, Spagnolo F, Marra E, Picasso V, Orgiano L, Marconcini R, De Rosa F, Di Guardo L, Galli G, Gandini S, Palmirotta R, Palmieri G, Queirolo P, Silvestris F and Italian Melanoma Intergroup (IMI).: Vitamin D in melanoma: Controversies and potential role in combination with immune check-point inhibitors. Cancer Treat Rev 69: 21-28, 2018. PMID: 29864718. DOI: 10.1016/ j.ctrv.2018.05.016

49 Garófolo A, Qiao L and Maia-Lemos PDS: Approach to nutrition in cancer patients in the context of the Coronavirus Disease 2019 (COVID-19) pandemic: Perspectives. Nutr Cancer: 1-9, 2020. PMID: 32696665. DOI: 10.1080/01635581.2020.1797126

50 Murai IH, Fernandes AL, Sales LP, Pinto AJ, Goessler KF, Duran CSC, Silva CBR, Franco AS, Macedo MB, Dalmolin HHH, Baggio J, Balbi GGM, Reis BZ, Antonangelo L, Caparbo VF, Gualano B and Pereira RMR: Effect of vitamin D supplementation $v s$. placebo on hospital length of stay in patients with severe covid-19: A multicenter, double-blind, randomized controlled trial. medRxiv: 2020. DOI: 10.1101/2020.11.16. 20232397

51 National Comprehensive Cancer Network. Breast Cancer (Version 6.2020). Available at: https://www.nccn.org/ professionals/physician_gls/pdf/breast_blocks.pdf [Last accessed on $1 / 1 / 2021]$

52 Heim N, Warwas FB, Wilms CT, Reich RH and Martini M: Vitamin D (25-OHD) deficiency may increase the prevalence of medication-related osteonecrosis of the jaw. J Craniomaxillofac Surg 45(12): 2068-2074, 2017. PMID: 29102331. DOI: 10.1016/ j.jcms.2017.09.015

53 Keshavarzi Z, Janghorban R, Alipour S, Tahmasebi S and Jokar A: The effect of vitamin $\mathrm{D}$ and $\mathrm{E}$ vaginal suppositories on tamoxifen-induced vaginal atrophy in women with breast cancer. Support Care Cancer 27(4): 1325-1334, 2019. PMID: 30729333. DOI: $10.1007 / \mathrm{s} 00520-019-04684-6$ 
54 Goulão B, Stewart F, Ford JA, MacLennan G and Avenell A: Cancer and vitamin D supplementation: a systematic review and meta-analysis. Am J Clin Nutr 107(4): 652-663, 2018. PMID: 29635490. DOI: $10.1093 /$ ajcn/nqx047

55 Tommie JL, Pinney SM and Nommsen-Rivers LA: Serum vitamin d status and breast cancer risk by receptor status: A systematic review. Nutr Cancer 70(5): 804-820, 2018. PMID: 29781719. DOI: 10.1080/01635581.2018.1470653

56 Estébanez N, Gómez-Acebo I, Palazuelos C, Llorca J and Dierssen-Sotos T: Vitamin D exposure and Risk of Breast Cancer: a meta-analysis. Sci Rep 8(1): 9039, 2018. PMID: 29899554. DOI: 10.1038/s41598-018-27297-1

57 Hossain S, Beydoun MA, Beydoun HA, Chen X, Zonderman AB and Wood RJ: Vitamin D and breast cancer: A systematic review and meta-analysis of observational studies. Clin Nutr ESPEN 30: 170-184, 2019. PMID: 30904218. DOI: 10.1016/j.clnesp. 2018.12.085

$58 \mathrm{Kim}$ Y and Je Y: Vitamin D intake, blood 25(OH)D levels, and breast cancer risk or mortality: a meta-analysis. Br J Cancer 110(11): 2772-2784, 2014. PMID: 24714744. DOI: 10.1038/ bjc. 2014.175

59 Ekmekcioglu C, Haluza D and Kundi M: 25-Hydroxyvitamin D status and risk for colorectal cancer and type 2 diabetes mellitus: A systematic review and meta-analysis of epidemiological studies. Int J Environ Res Public Health 14(2): 127, 2017. PMID: 28134804. DOI: 10.3390/ijerph 14020127

60 Garland CF and Gorham ED: Dose-response of serum 25hydroxyvitamin $\mathrm{D}$ in association with risk of colorectal cancer: A meta-analysis. J Steroid Biochem Mol Biol 168: 1-8, 2017. PMID: 27993551. DOI: 10.1016/j.jsbmb.2016.12.003

61 Choi YJ, Kim YH, Cho CH, Kim SH and Lee JE: Circulating levels of vitamin D and colorectal adenoma: A case-control study and a meta-analysis. World J Gastroenterol 21(29): 8868 8877, 2015. PMID: 26269676. DOI: 10.3748/wjg.v21.i29.8868

62 Zhang Y, Fang F, Tang J, Jia L, Feng Y, Xu P and Faramand A: Association between vitamin D supplementation and mortality: systematic review and meta-analysis. BMJ 366: 14673, 2019. PMID: 31405892. DOI: 10.1136/bmj.14673

63 Keum N, Lee DH, Greenwood DC, Manson JE and Giovannucci E: Vitamin D supplementation and total cancer incidence and mortality: a meta-analysis of randomized controlled trials. Ann Oncol 30(5): 733-743, 2019. PMID: 30796437. DOI: 10.1093/ annonc/mdz059

64 Gaksch M, Jorde R, Grimnes G, Joakimsen R, Schirmer H, Wilsgaard T, Mathiesen EB, Njølstad I, Løchen ML, März W, Kleber ME, Tomaschitz A, Grübler M, Eiriksdottir G, Gudmundsson EF, Harris TB, Cotch MF, Aspelund T, Gudnason V, Rutters F, Beulens JW, van 't Riet E, Nijpels G, Dekker JM, Grove-Laugesen D, Rejnmark L, Busch MA, Mensink GB, Scheidt-Nave C, Thamm M, Swart KM, Brouwer IA, Lips P, van Schoor NM, Sempos CT, Durazo-Arvizu RA, Škrabáková Z, Dowling KG, Cashman KD, Kiely M and Pilz S: Vitamin D and mortality: Individual participant data meta-analysis of standardized 25-hydroxyvitamin D in 26916 individuals from a European consortium. PLoS One 12(2): e0170791, 2017. PMID: 28207791. DOI: 10.1371/journal.pone.0170791
65 Vaughan-Shaw PG, O'Sullivan F, Farrington SM, Theodoratou E, Campbell H, Dunlop MG and Zgaga L: The impact of vitamin D pathway genetic variation and circulating 25hydroxyvitamin $\mathrm{D}$ on cancer outcome: systematic review and meta-analysis. Br J Cancer 116(8): 1092-1110, 2017. PMID: 28301870. DOI: $10.1038 /$ bjc.2017.44

66 Bjelakovic G, Gluud LL, Nikolova D, Whitfield K, Krstic G, Wetterslev J and Gluud C: Vitamin D supplementation for prevention of cancer in adults. Cochrane Database Syst Rev (6): CD007469, 2014. PMID: 24953955. DOI: 10.1002/14651858. CD007469.pub2

67 Maalmi H, Walter V, Jansen L, Boakye D, Schöttker B, Hoffmeister $\mathrm{M}$ and Brenner H: Association between blood 25hydroxyvitamin D levels and survival in colorectal cancer patients: An updated systematic review and meta-analysis. Nutrients 10(7), 2018. PMID: 30011816. DOI: 10.3390/ nu 10070896

68 Xu J, Yuan X, Tao J, Yu N, Wu R and Zhang Y: Association of circulating 25-hydroxyvitamin D levels with colorectal cancer: An updated meta-analysis. J Nutr Sci Vitaminol (Tokyo) 64(6): 432-444, 2018. PMID: 30606966. DOI: 10.3177/jnsv.64.432

69 Ou B, Zhao J, Guan S and Lu A: Plasma 25-hydroxyvitamin D levels and survival of colorectal cancer patients: a meta-analysis. Eur J Cancer 51(6): 786-788, 2015. PMID: 25746389. DOI: 10.1016/j.ejca.2015.01.010

70 Soares AM, Szejnfeld VL, Enokihara MY, Michalany N and Castro CH: High serum 25-hydroxyvitamin D concentration in patients with a recent diagnosis of non-melanoma skin cancer: a case-control study. Eur J Dermatol 28(5): 649-653, 2018. PMID: 30355545. DOI: 10.1684/ejd.2018.3401

71 Irving A, Duchow E, Plum L and Deluca H: Vitamin D deficiency in the Apc Pirc/+ rat does not exacerbate colonic tumorigenesis, while low dietary calcium might be protective. Disease Models \& Mechanisms 11(3): dmm032300, 2018. PMID: 29590632. DOI: 10.1242/dmm.032300

72 Kwan AK, Um CY, Rutherford RE, Seabrook ME, Barry EL, Fedirko V, Baron JA and Bostick RM: Effects of vitamin D and calcium on expression of MSH2 and transforming growth factors in normal-appearing colorectal mucosa of sporadic colorectal adenoma patients: A randomized clinical trial. Mol Carcinog 58(4): 511-523, 2019. PMID: 30499618. DOI: $10.1002 / \mathrm{mc} .22945$

73 Jeon SM and Shin EA: Exploring vitamin D metabolism and function in cancer. Exp Mol Med 50(4): 20, 2018. PMID: 29657326. DOI: 10.1038/s12276-018-0038-9

74 Mahamat-Saleh Y, Aune D and Schlesinger S: 25Hydroxyvitamin D status, vitamin D intake, and skin cancer risk: a systematic review and dose-response meta-analysis of prospective studies. Scientific Reports 10(1), 2020. DOI: 10.1038/s41598-020-70078-y 